\title{
Preliminary Study on the Effect of Wastewater Storage in Septic Tank on E. coli Concentration in Summer
}

\author{
Dominique Appling ${ }^{1}$, Mussie Y. Habteselassie ${ }^{1, *}$, David Radcliffe ${ }^{2}$ and James K. Bradshaw ${ }^{2}$ \\ 1 Department of Crop and Soil Sciences, University of Georgia Griffin Campus, 1109 Experiment \\ Street, Griffin, GA 30223, USA; E-Mail: appling_dominique@yahoo.com \\ 2 Department of Crop and Soil Sciences, University of Georgia, 3111 Miller Plant Sciences Building, \\ Athens, GA 30602, USA; E-Mails: dradclif@uga.edu (D.R.); jbradsha@uga.edu (J.B.) \\ * Author to whom correspondence should be addressed; E-Mail: mussieh@uga.edu; \\ Tel.: +1-770-229-3336; Fax: +1-770-228-7271.
}

Received: 10 May 2013; in revised form: 5 July 2013 / Accepted: 19 July 2013 /

Published: 26 July 2013

\begin{abstract}
On-site wastewater treatment systems (OWTS) work by first storing the wastewater in a septic tank before releasing it to soils for treatment that is generally effective and sustainable. However, it is not clear how the abundance of E. coli changes during its passage through the tank. In this study, which was conducted under the UGA young Scholar Program in summer of 2010, we examined the change in wastewater quality parameters during the passage of the wastewater through the tank and after its release into soil. We collected wastewater samples at the inlet and outlet of an experimental septic tank in addition to obtaining water samples from lysimeters below trenches where the drainpipes were buried. We report that $E$. coli concentration was higher by 100 -fold in the septic tank effluent than influent wastewater samples, indicating the growth of $E$. coli inside the tank under typical Georgian summer weather. This is contrary to the assumption that $E$. coli cells do not grow outside their host and suggests that the microbial load of the wastewater is potentially enhanced during its storage in the tank. Electrical conductivity, $\mathrm{pH}$ and nitrogen were similar between the influent and effluent wastewater samples. E. coli and total coliform concentrations were mainly below detection in lysimeter samples, indicating the effectiveness of the soil in treating the wastewater.
\end{abstract}

Keywords: on-site wastewater treatment systems; E. coli; total coliform; growth; septic tank; piedmont 


\section{Introduction}

Nationally, more than a quarter of US households employ on-site wastewater systems (OWTS) to treat and dispose wastewater [1]. In Georgia, the percent use of OWTS is higher than the national average at about $37 \%$. These systems, also known as septic systems, are commonly designed to accumulate the waste in a two-chamber tank where solids settle while the wastewater flows to a distribution box that is connected to one or more perforated drainpipes that distribute wastewater to the soil. The drainpipes are commonly installed in trenches and surrounded by a supporting material such as gravel or polystyrene to prevent clogging. Wastewater treatment occurs in the soil via biological (predation, die-off), chemical (adsorption) and physical (filtration) mechanisms before it reaches the surrounding ground or surface waters $[1,2]$. OWTS must, therefore, be installed in suitable soils that can accomplish the treatment processes properly [3-5].

In general, OWTS are an effective and sustainable way of treating wastewater. OWTS can negatively impact the microbial quality of surrounding water bodies. This is mainly true if OWTS are failing, which could happen due to installation of OWTS in unsuitable soils, age of the system, excessive use of water, or poor maintenance [6,7]. Properly functioning OWTS can also contaminate surrounding water bodies at times of extreme weather [8,9]. This happens due to excessive moisture in soils that decreases the depth of the unsaturated layer where the wastewater is treated before it reaches the ground water below. In the presence of excessive soil moisture, the downward movement of the wastewater is facilitated without allowing enough time for it to interact with the soil environment for treating the contaminants.

Contaminants of concern commonly associated with OWTS are microbial pathogens and nutrients (mainly nitrogen), which are the leading causes of water quality impairments in US streams and rivers [10]. There are technologies that can be retrofitted into existing OWTS to reduce the amount of contaminants in the wastewater effluent. These technologies are commonly called advanced treatment units and work by mainly manipulating the oxygen and carbon content of the wastewater [11-13]. In pre-anoxic units, for example, the wastewater is made to pass through an aerobic unit that is retrofitted between the septic tank and the drainfield to nitrify the ammonium into nitrate. The nitrified wastewater is then recycled back to the anoxic septic tank where it is denitrified in the presence of a carbon source. In another variation, the septic system is fitted with an aerobic unit before the septic tank to facilitate the processes of nitrification and denitrification to sequentially remove nitrogen. The limited field studies carried out so far to evaluate the effectiveness of these units mainly focused on nitrogen $[14,15]$. The impact of these units on the microbial load of the wastewater is largely unknown. The technologies are not yet popular throughout the United States as they are expensive [16].

Previous studies that looked at the impact of OWTS on water quality had mainly focused on how well wastewater is treated in soils before it joins water bodies directly by installing monitoring wells around these systems, e.g., $[9,17]$ or indirectly by comparing water quality in areas with varying densities of OWTS, e.g., [18]. While these approaches are sound, they do not give us any information on the kind of microbial transformation the wastewater undergoes when stored in the septic tank. This is important because it might affect the microbial contaminant load of the wastewater when it leaves the tank. In this study, which was conducted under the UGA Young Scholar Program in June of 2010, we examined the change in the quality of the wastewater before it gets to and after it leaves the septic 
tank but before it is released to soil. Water samples were also collected from suction lysimeters installed below the trenches of the OWTS in a typical Georgian soil (red clay soil) into which the wastewater was released for treatment. We were particularly interested in investigating whether $E$. coli cells were capable of multiplying in the septic tank.

\section{Materials and Methods}

\subsection{Study Site and On-site Wastewater Treatment System (OWTS)}

The wastewater and water samples in this study were collected from an experimental on-site wastewater treatment system (OWTS) that was installed at the Westbrook Farm of the University of Georgia, Griffin Campus in 2008 [19]. Briefly, the system consisted of an above-ground dosing tank (4170 L capacity) where residential strength wastewater obtained from Cabin Creek Wastewater Treatment Plant in Griffin, GA was stored before it was dosed to a 3875 L capacity septic tank. The retention time for the wastewater in the septic tank was 6 days. The wastewater was dosed to the drainfield at a rate of $648 \mathrm{~L}$ per day. The dosing schedule was three times per day every $8 \mathrm{~h}$, with the total dose being divided evenly over that time period. The Cabin Creek Plant served a residential area and monthly Georgia Environmental Protection Division (EPD) reports provided by the wastewater treatment plant verified that the wastewater was residential-strength as defined by five-day biochemical oxygen demand (BOD5) and total suspended solids (TSS), respectively, 45.2 and $35 \mathrm{mg}$ per L [20]. The wastewater was tested for BOD5 and TSS before dosing to make sure that they were of residential-strength. The BOD5 and TSS values showed as much as $50 \%$ variation among measurements during different sampling times in June 2010. Wastewater was collected from the inlet of the wastewater treatment plant and transported to the site twice per week. The wastewater was then released from the septic tank into three drain pipes via a distribution box. The perforated drain pipes were installed in $10 \mathrm{~m}$ gravel trenches in a Cecil series soil (fine kaolinitic thermic typic kanhapudult) [19]. The trenches were installed in the B-horizon, which had two layers, Bt1 and Bt2. The texture of the Bt1 and Bt2 was clay and sandy clay, with saturated hydraulic conductivity $\left(\mathrm{K}_{\mathrm{s}}\right)$ of $5.7-65$ and $22-31 \mathrm{~cm} / \mathrm{d}$, respectively. The soil porosity in the Bt1 and Bt2 layers was 39 and $30 \%$, respectively.

The septic tank was installed in the ground with approximately $15 \mathrm{~cm}$ protruding from the surface to allow easy access for sampling. The septic tank was dosed every 8 hours for two years. For this particular study, however, influent (SIN) and effluent (SOUT) wastewater samples from the septic tank were collected once a week for three consecutive weeks in June 2010 (3, 10 and 17 June). Water samples were also collected from ceramic suction-cup lysimeters that were installed $15 \mathrm{~cm}$ below the trenches, which were approximately $70 \mathrm{~cm}$ below the soil surface, using a hand held vacuum pump into sterile plastic bottles. The samples were stored in a cooler with ice until they were taken to the laboratory within a few hours for testing.

\subsection{Water Quality Parameters}

The $\mathrm{pH}$ and electrical conductivity (EC) of the wastewater and water samples were measured by using a hand held probe (ORION 3 Star, Thermo Scientific, Beverly, MA, USA) in duplicates. The probes were calibrated with standard solutions before every measurement according to the instructions 
of the manufacturer. SIN and SOUT samples collected on 3 and 24 June 2010 were also analyzed for ammonium and nitrate. Ammonium and nitrate were determined calorimetrically using the Phenate and the Cadmium Reduction methods [21], respectively. The samples were also tested for total coliform and E. coli by using the IDEXX Colilert- $18^{\circledR}$ kit, which has a detection limit of 1 organism per $100 \mathrm{ml}$ (IDEXX Laboratories, Inc., Westbrook, ME, USA) in duplicates. Based on the number of positive wells in the 97-well tray (positive was indicated by a yellow color for total coliform and UV fluorescence for E. coli), the corresponding most probable number (MPN) value per $100 \mathrm{~mL}$ sample was obtained with manufacturer supplied MPN tables [22].

\subsection{Statistical Analysis}

A two-way Analysis of Variance (ANOVA) was done on the $\mathrm{pH}, \mathrm{EC}$, nitrogen, total coliform and E. coli data to investigate the statistical significance of the effect of time (week) and location (septic tank inlet, outlet, trench 1-3) on these parameters in SAS 9.3 (SAS Institute, Inc., City, NC, USA) at significance level of $\alpha=0.05$. One way ANOVA was also done on individual data sets to examine the significance of the effect of one of the factors (e.g., time or position) at a time. A pair-wise t-test was also done on $E$. coli data to compare the septic tank influent and effluent samples for each time period separately. The data were either log or inverse transformed to fulfill the assumptions of the models used for analysis.

\section{Results}

\subsection{Common Water Quality Parameters}

Influent and effluent wastewater samples had significantly higher $\mathrm{pH}(\mathrm{P}<0.0001)$ and $\mathrm{EC}(\mathrm{P}<0.0002)$ values than the water samples collected from lysimeters $15 \mathrm{~cm}$ below the trench bottoms (Figure 1). The $\mathrm{pH}$ values of the influent and effluent wastewater samples were similar over the three-week time, averaging about 7.4 (Figure 1A). The EC values were also similar for the two wastewater samples, with the three-week average of 673 and $678 \mu \mathrm{s} \mathrm{cm}^{-1}$ for the influent and effluent samples, respectively (Figure 1B). The $\mathrm{pH}$ values for the trench samples ranged between 6.5 and 6.8 , which were 0.6 to 0.9 units below the wastewater samples. The EC values for the trench samples ranged between 285 and $378 \mu \mathrm{s} \mathrm{cm}^{-1}$, which were on average $50 \%$ lower than the wastewater samples (Figure 1). The effect of time was not significant on either $\mathrm{pH}(\mathrm{P}=0.1413)$ or $\mathrm{EC}(\mathrm{P}=0.4577)$. The average ammonium concentration for two sampling times (June 3 and 24) for SIN and SOUT samples were 34.93 and $33.57 \mathrm{mg} \mathrm{NH}_{4}{ }^{+}-\mathrm{N}$ per $\mathrm{L}$, respectively, while nitrate concentration was below detection (0.02 $\mathrm{mg} \mathrm{NO}_{3}{ }^{-}-\mathrm{N}$ per L). There was no significant difference between the SIN and SOUT samples in regards to nitrogen. We did not see any time effect either on these nitrogen forms. The dominance of ammonium in both sample types indicates that nitrification was limited in the septic tank, which is anoxic. 
Figure 1. $\mathrm{pH}$ (A) and electrical conductivity (EC); (B) values of wastewater samples from septic tank inlet (SIN) and outlet (SOUT), in addition to water samples from lysimeters installed $15 \mathrm{~cm}$ below the drainfield trenches (T1, T2 and T3). Wastewater and water samples were collected on June 3 (week 1), June 10 (week 2) and June 17 (week 3).

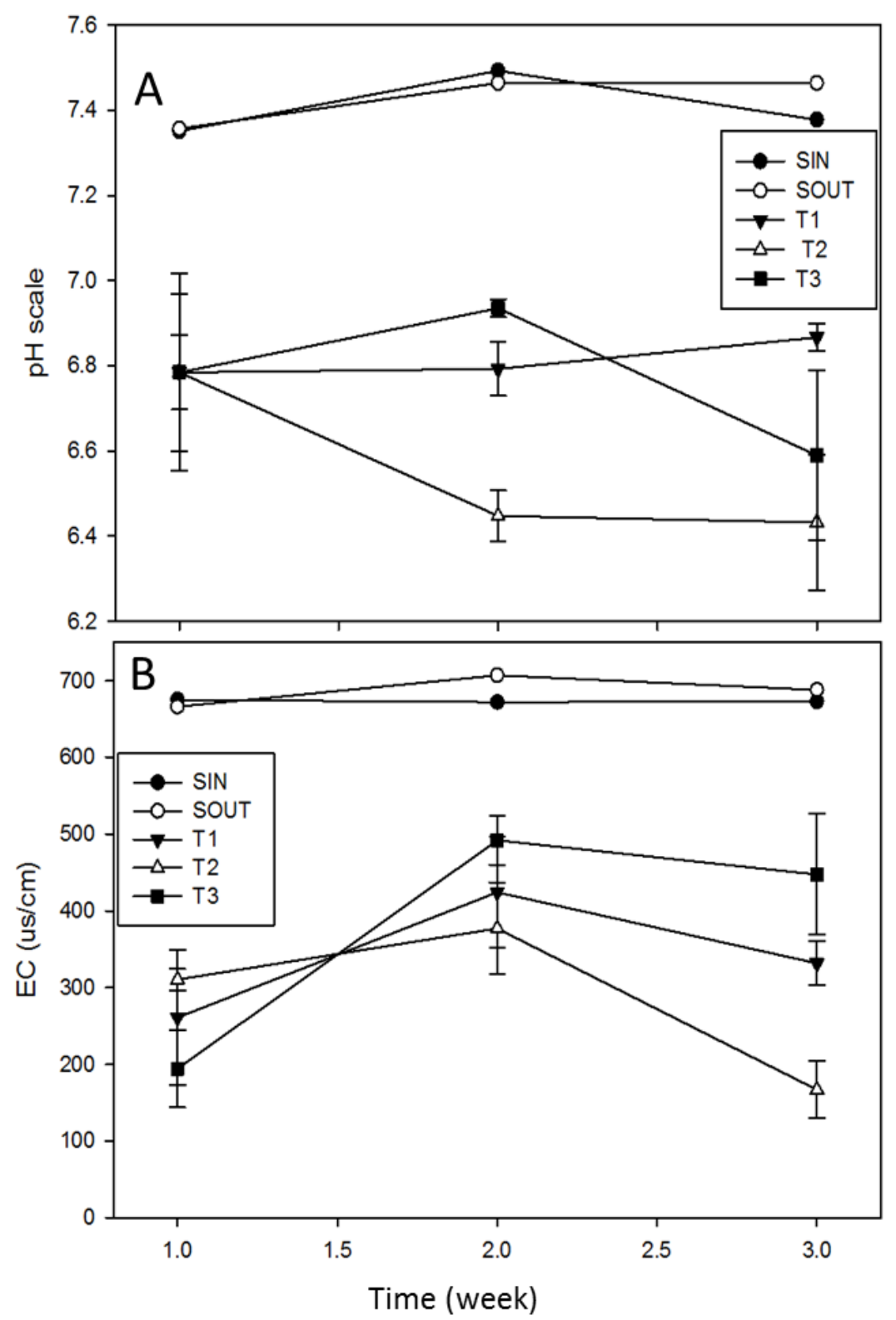

\subsection{Fecal Indicator Bacteria}

Based on a two-way ANOVA, the main effect of location (septic tank inlet, septic tank outlet, trench 1, 2 and 3) on E. coli concentration was statistically significant $(\mathrm{P}=0.0004)$, while the effect of time (week 1, 2 or 3 ) was not $(\mathrm{P}=0.9914)$. E. coli concentrations in the septic tank influent samples were 3.1, 3.2 and $4.3 \mathrm{log}$ per $100 \mathrm{~mL}$ while the concentrations in the septic tank effluent were 5.3, 5.3 and $4.3 \mathrm{log}$ per $100 \mathrm{~mL}$ for the first, second and third week of sampling, respectively, indicating a 100 -fold increase in E. coli concentration in the effluent samples in the first and second weeks (Figure 2A). A pair-wise t-test on E. coli concentrations of septic tank influent and effluent samples 
for the individual sampling week indicated that the difference was statistically significant for weeks 1 $(\mathrm{P}=0.0016)$ and $2(\mathrm{p}=0.0016)$ but not week $3(\mathrm{p}=0.6174)$. E. coli concentrations in the trenches were below detection.

Figure 2. (A) E. coli; and total coliform (B) counts of wastewater samples from septic tank inlet (SIN) and outlet (SOUT), in addition to water samples from lysimeters installed $15 \mathrm{~cm}$ below drainfield trenches (T1, T2 and T3). Wastewater and water samples were collected on June 3 (week 1), June 10 (week 2) and June 17 (week 3).

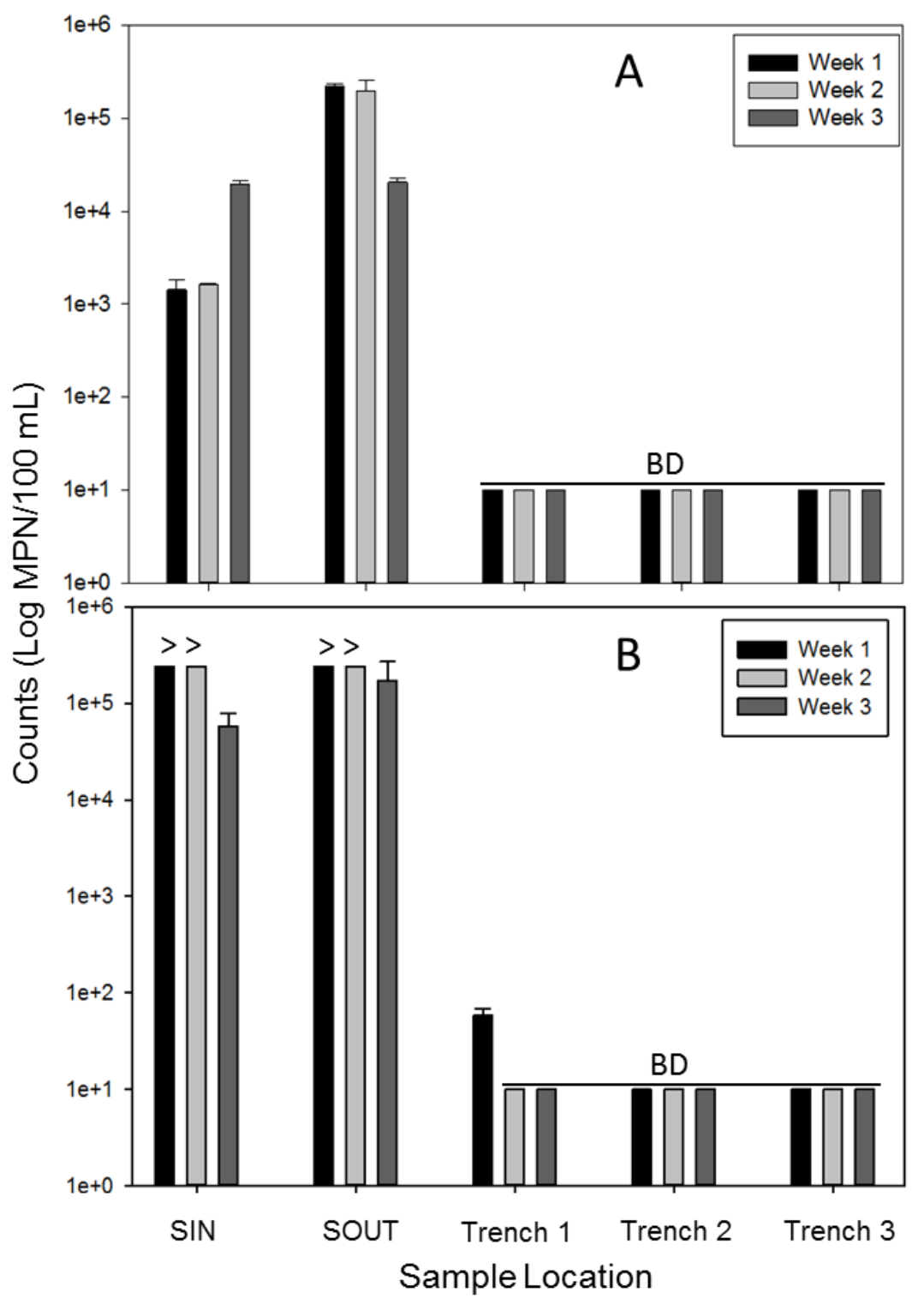

Notes: $>=$ greater than indicated concentration; $\mathrm{BD}=$ below detection .

Total coliform concentrations were above the maximum level of detection $(>5.38 \log$ MPN per $100 \mathrm{~mL})$ at the dilution level that was employed during testing (1:100) for the septic tank influent and effluent samples for weeks 1 and 2 (Figure 2B). For week 3, however, total coliform concentrations were higher in the septic effluent samples $(5.24 \log$ per $100 \mathrm{~mL})$ than the septic influent samples (4.76 log MPN per $100 \mathrm{~mL}$ ). Total coliform were below detection levels (BD) in trench water samples except for water samples on the first week in trench 1. 


\section{Discussions}

As indicated by the $\mathrm{pH}, \mathrm{EC}$, ammonium and nitrate concentrations, there was not a significant change in the chemical property of the wastewater during its passage through the septic tank. These parameters are commonly used as chemical water quality indicators. There was, however, a significant change in its microbiological property. The increase in E. coli concentration in the effluent samples indicated that $E$. coli was able to grow inside the septic tank under typical summer weather in GA. The maximum air temperatures during the sampling days were close to the ideal growth temperature for E. coli, with $29.21,31.84$ and $32.86{ }^{\circ} \mathrm{C}$ for the first, second and third sampling times, respectively (Figure 3). The maximum relative humidity was also high, with $98.5 \%, 89.8 \%$ and $98.6 \%$ for the first, second and third sampling times, respectively (Figure 3). Temperatures in the septic tank were not measured. Since the top $15 \mathrm{~cm}$ of the tank was exposed, it can be expected that the temperatures in the tank were somewhat higher than the temperatures in a typical septic tank where the top is approximately $30 \mathrm{~cm}$ below the surface. This pattern of $E$. coli growth can also be expected to happen in other summer months, which are warmer than June in GA (e.g., July and August) [23].

Our study supports previous findings of growth of E. coli in tropical soils with similar type of weather [24-26]. To our knowledge, however, growth of $E$. coli in septic tanks has not been previously reported. Ottoson and Stenstrom [27] reported the growth of Enterococci and Salmonella in sterilized sediment from a settling tank of greywater in a laboratory study in Sweden but the bacteria did not grow in unsterilized sediment. This is different from our study in that greywater does not include the solid waste from the toilet and that the growth of the bacteria happened only after removal of the indigenous microorganisms through sterilization. They also did not investigate the growth of $E$. coli in the sediment. The fact that $E$. coli is capable of multiplying in environments other than the guts of warm-blooded animals undermines the original assumption under which $E$. coli was recommended to be used as indicator of microbial water quality [28,29]. The implication of E. coli growth in septic tanks is that the bacterium or other pathogens could be introduced into the soil environment at enhanced concentrations. This can potentially saturate the adsorption capacity of the coarse textured soils, which are widely found in coastal areas, facilitating their downward movement to groundwater sources [4]. We observed E. coli growth in the septic tank in the first two weeks, but not in the third week. We are not sure why as the environmental conditions such as temperature and relative humidity were not that different among the three days (3,10 and 17 June) the samples were collected (Figure 3).

Existing technologies to enhance the performance of OWTS involve the use of advanced treatment units that manipulate the oxygen content of the wastewater to enhance the nitrification-denitrification processes to reduce the level of nitrogen (nitrate) in the wastewater before its release to the environment [11]. This has been shown to be quite effective in reducing nitrogen load of the wastewater [15]. However, its impact on microbial contaminants is not yet clear. The aeration step in this process could potentially enhance the growth of $E$. coli, which is a facultative anaerobe.

The substantial decrease in EC of trench water samples or the non-detection of E. coli or total coliform in the trench water samples indicated that the soil was very effective in treating the wastewater. The textures of the B horizons where the trenches were located ranged from sandy clay to clay, indicating the dominance of the clay fraction in the soil. Clay soils are highly effective in adsorbing viruses under a number of different environmental conditions, including during rainfall [30,31]. Bacteria will also be 
similarly affected by clay soils due to their surface charges. The capacity of the clay soils to adsorb microorganisms even under high soil moisture conditions prevents their downward migration to the ground water. Rapid movement of microbial contaminants in the soil originating from septic systems has mainly been reported in sandy soils or karst topography that is characterized by large fissures and cracks $[4,32]$.

Figure 3. Minimum (min), average (mean) and maximum (max) daily (A) air temperature; and (B) relatively humidity for the month of June 2010 for the study site. Wastewater and water samples were collected on June 3 (week 1), June 10 (week 2) and June 17 (week 3).

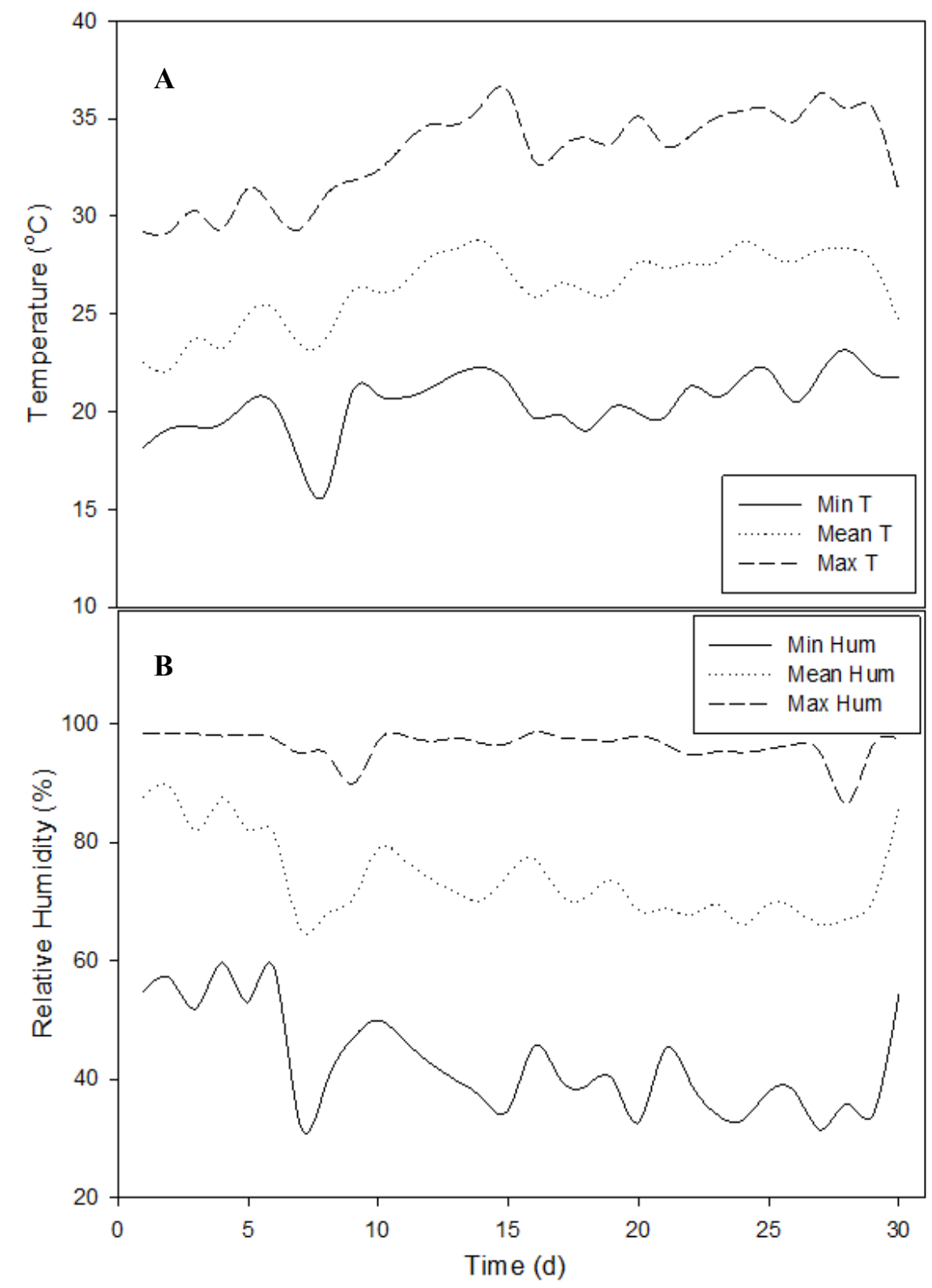

The microbial counts of the water samples from below the trenches might have been underestimated because of how they were collected. These were collected in suction samplers that have ceramic cups with an approximate pore diameter of $1.44 \mu \mathrm{m}$, based on the reported air-entry value of $200 \mathrm{kPa}$ (Soil Moisture Equipment, Santa Barbra, CA, USA). The water samples travel through these pores into the cups because of water potential gradient between the soil and the inside of the cup. The pores are large 
enough to allow most bacteria to travel through, including $E$. coli whose size is about $0.55 \mu \mathrm{m}$ in diameter [33]. However, because of the tortuous nature of the network of the pores, it is possible that the bacteria might get filtered out.

The variability of the data among the replicates for each sampling time was different for the SIN and SOUT samples. For E. coli, for example, the standard errors (SEs) ranged between $0.6 \%$ and $7.9 \%$ of the means for SIN samples. For the SOUT samples, the SEs ranged between $6.1 \%$ and $21.8 \%$ of the means. The variability was reasonable enough to result in significantly different means between SIN and SOUT samples for the first and second weeks. The variability increased when the three weeks E. coli data were pooled together. The SEs were $50 \%$ and $29 \%$ of the means for the SIN and SOUT samples, respectively, the difference mainly being between weeks $1 \& 2$ and week 3 (Figure 2). The large variability among the pooled data for the three-week time was probably the reason why sampling time did not have a significant effect on E. coli concentration (see Section 3.2). More frequent and longer sampling scheme that includes different seasons might be more appropriate to investigate the effect of time on E. coli growth.

\section{Conclusions}

The study reports the growth of $E$. coli in wastewater inside a septic tank under typical summer weather in Georgia, USA. This finding suggests that the bacterium or other pathogens could be introduced into the soil environment for treatment, as is the case for OWTS, at enhanced concentrations. This can potentially saturate the adsorption capacity of the coarse textured soils, facilitating their downward movement to groundwater sources. The growth of E. coli inside a septic tank is also contrary to the assumption under which $E$. coli is used as a water quality indicator. Further studies are required to identify the specific types of $E$. coli that are growing in the septic tank, in addition to the impact of retrofit technologies for enhancing OWTS performance on growth behavior of E. coli in septic tanks. Because of the short term and limited nature of the study, future long term studies are also needed to confirm the findings of this study over a multiple season period, preferably targeting OWTS that are in use by homeowners.

\section{Acknowledgements}

The authors would like to acknowledge Bobby Goss and Vijayalakshmi Mantripragada for their help during the field and laboratory work. The authors would also like to thank the UGA Young Scholars Program for providing summer support for Dominique Appling in 2010.

\section{References}

1. U.S. Environmental Protection Agency (USEPA). Onsite Wastewater Treatment Systems Manual; USEPA: Washington, DC, USA, 2002; EPA/625/R-00/008.

2. Gerba, C.; Smith, J.E., Jr. Sources of pathogenic microorganisms and their fate during land application of wastes. J. Environ. Qual. 2005, 34, 42-48. 
3. Oakley, S.; Greenwood, W.P.; Lee, M. Monitoring Nitrogen and Virus Removal in the Vadose One with Suction Lysimeters. In Proceedings of 10th Northwest On-site Wastewater Treatment Short Course and Equipment Exhibition, Seattle, WA, USA, 20-21September 1999; University of Washington: Seattle, WA, USA, 1999; pp 221-232.

4. Paul, J.H.; McLaughlin, M.R.; Griffin, D.W.; Lipp, E.K.; Stokes, R.; Rose, J.B. Rapid movement of wastewater from onsite disposal systems into surface waters in the lower Florida keys. Estuaries 2000, 23, 662-668.

5. Van Cuyk, S.; Siegrist, R.L.; Lowe, K.; Harvey, R.W. Evaluating microbial purification during soil treatment of wastewater with multicomponent tracer and surrogate tests. J. Environ. Qual. 2004, 33, 316-329.

6. Ahmed, W.; Neller, R.; Katouli, M. Evidence of septic system failure determined by a bacterial biochemical fingerprinting method. J. Appl. Microbiol. 2005, 98, 910-920.

7. Keswick, B.H.; Gerba, C.P. Viruses in groundwater. Environ. Sci. Technol. 1980, 14, 1290-1297.

8. Arnade, L.J. Seasonal correlation of well contamination and septic tank distance. Ground Water 1999, 37, 920-923.

9. Habteselassie, M.Y.; Kirs, M.; Conn, K.E.; Blackwood, A.D.; Kelly, G.; Noble, R.T. Tracking microbial transport through four onsite wastewater treatment systems to receiving waters in eastern north Carolina. J. Appl. Microbiol. 2011, 111, 835-847.

10. U.S. Environmental Protection Agency. National Summary of Impaired Waters and TMDL Information. Available online: http://iaspub.epa.gov/waters10/attains_nation_cy.control? p_report_type $=\mathrm{T}$ (accessed on 31 May 2013).

11. Oakley, S.M.; Gold, A.J.; Oczkowski, A.J. Nitrogen control through decentralized wastewater treatment: Process performance and alternative strategies. Ecol. Engineer. 2010, 36, 1520-1531.

12. Moore, B. Innovative and Alternative System Use in Rhode Island. Personal Communication; Rhode Island Department of Environmental Management (RIDEM): Providence, RI, USA, 2008.

13. Rhode Island Department of Environmental Management (RIDEM). Rules Establishing Minimum Standards Relating to Location, Design, Construction and Maintenance of Onsite Wastewater Treatment Systems; Personal Communication; RIDEM: Providence, RI, USA, 2008.

14. Rich, B. Overview of the field test of innovative on-site wastewater treatment systems during the La Pine National Demonstration Project. J. Hydrologic Eng.2008, 13, 752-760.

15. National Sanitation Foundation (NSF) International. Pennsylvania ONLOT Technology Verification Program; NSF International: Ann Arbor, MI, USA, 2009.

16. Obropta, C.C.; Berry, D. Onsite Wastewater Treatment Systems: Alternative Technologies; Rutgers University Cooperative Research and Extension: New Brunswick, NJ, USA, 2005.

17. Humphrey, C.P.; O’Driscoll, M.A.; Zarate, M.A. Evaluation of on-site wastewater system Escherichia coli contributions to shallow groundwater in costal North Carolina. Water Sci. Technol. 2011, 63, 789-795.

18. Carroll, S.; Hargreaves, M.; Goonetilleke, A. Source tracking pollution from onsite wastewater treatment systems in surface waters using antibiotic resistance analysis. J. Appl. Microbiol. 2005, 99, 471-482. 
19. Bradshaw, J.K.; Radcliffe, D.E. Nitrogen Dynamics in a Piedmont Wastewater Treatment System. In Proceedings of the 2011 Georgia Water Resources Conference, Athens, GA, USA, 11-13 April 2011; Carroll, D., Ed.; Georgia Water Resources Association: Athens, GA, USA, 2011; pp 110-113.

20. Georgia Department of Human Resources-Division of Public Health (GADHR-DPH). Manual for Onsite Sewage Management Systems. Available online: http:/health.state.ga.us/pdfs/ environmenta1/LandUse/Manual/CompleteOnsiteManual.pdf (accessed on 8 March 2013).

21. American Public Health Association (APHA); American Water Works Association (AWWA); Water Pollution Control Research (WPCR). Standard Methods for the Examination of Water and Wastewater, 20th ed.; APHA: Washington, DC, USA, 1999.

22. Hurley, M.A.; Roscoe, M.E. Automated statistical analysis of microbial enumeration by dilution series. J. Appl. Bacteriol. 1983, 55, 159-164.

23. Georgia Weather Net Home Page. Available online: http://www.georgiaweather.net/ (accessed on 10 April 2013).

24. Byappanahalli, M.; Fujioka, R. Indigenous soil bacteria and low moisture may limit but allow faecal bacteria to multiply and become minor population in tropical soils. Water Sci. Technol. 2004, 50, 27-32.

25. Fujioka, R.S. Monitoring coastal marine waters for spore-forming bacteria of faecal and soil origin to determine point from non-point source pollution. Water Sci. Technol. 2001, 44, 181-188.

26. Ishii, S.; Ksoll, W.B.; Hicks, R.E.; Sadowsky, M.J. Presence and growth of naturalized Escherichia coli in temperate soils from Lake Superior watersheds. Appl. Environ. Microbiol. 2006, 72, 612-621.

27. Ottoson, J.; Stenstrom, T.A. Faecal contamination of greywater and associated microbial risks. Water Research 2003, 37, 645-655.

28. Leclerc, H.; Mossel, D.A.A.; Edberg, S.C.; Struijk, C.B. Advances in the bacteriology of the coliform group: Their suitability as markers of microbial water safety. Annu. Rev. Microbiol. 2001, 55, 201-234.

29. United States Environmental Protection Agency (USEPA). Ambient Water Quality Criteria for Bacteria; United States Environmental Protection Agency: Washington, DC, USA, 1986.

30. Meschke, J.S.; Sobsey, M.D. Comparative adsorption of Norwalk virus, Poliovirus 1 and F + RNA coliphage MS2 to soils suspended in treated wastewater. Water Sci. Technol. 1998, 38, 187-189.

31. Sobsey, M.D.; Dean, C.H.; Knuckles, M.E.; Wagner, R.A. Interactions and survival of enteric viruses in soil materials. Appl. Environ. Microbiol.1980, 40, 92-101.

32. Scandura, J.E.; Sobsey, M.D. Viral and bacterial contamination of groundwater from on-site sewage treatment systems. Water Sci. Technol. 1997, 35, 141-146.

33. Trueba, F.J.; Woldringh, C.L. Changes in cell diameter during the division cycle of Escherichia coli. J. Bacteriol. 1980, 142, 869-878.

(C) 2013 by the authors; licensee MDPI, Basel, Switzerland. This article is an open access article distributed under the terms and conditions of the Creative Commons Attribution license (http://creativecommons.org/licenses/by/3.0/). 